\title{
THE ARBITRAL AWARD OF 18.7.2014 IN THE VETERAN PERTOLEUM V. RUSSIA CASE
}

\author{
Marek Jeżewski*
}

\section{Introduction}

On 18.7.2014, an Arbitral Tribunal composed of L. Yves Fortier, Ch. Poncet and S. Schwebel issued three awards in cases brought by Veteran Petroleum Limited (Cyprus), Hulley Enterprises Limited (Cyprus) and Yukos Universal Limited (Isle of Man) (together as the "Claimants") against Russia (together as the "Yukos Awards") ${ }^{1}$ for the violation by Russia of the Energy Charter Treaty due to its treatment of Yukos, which was once the largest oil company in Russia. The Award was noted worldwide not only by the international investment law community but also by the general public. Yet, the landmark nature of the Yukos Awards does not result solely from the political context or the amount of damages awarded by the Tribunal, but also from the complexity and importance of legal issues that it dealt with.

* Ph.D, Partner at Kochański, Zięba Rapala and Partners (“KZRP”). The views presented in the present case comment are the Author's personal opinion and need not represent the opinion of KZRP.

1 All three awards are available on www.pca-cpa.org. The Tribunal issued three virtually identical awards. All the references to the Yukos Awards in the present case-comment are to the Veteran Pertoleum v. Russia Award. 
After a short description of the facts of the case (part 2), the present case comment focuses on those salient legal issues in the following order: the issue of the host State's regulatory and enforcement powers with respect to taxation (part 3), the issue of relationship between a claim of expropriation and the bad faith of the state (part 4); the issue of contributory fault (part 5); and the issue of calculation of lucrum cessans (part 6).

\section{Facts}

In very general terms, the dispute between the Claimants and Russia concerned the treatment by Russia of Yukos, one of the leading oil companies in Russia until 2003. Yukos was a privatized company involved in exploration, production, refining, marketing and distribution of crude oil, natural gas and petroleum products. Mr. Khodorkovsky together with his business partners invested in Yukos in 1996 under the "shares for loans" program developed by President Yeltsin's administration ${ }^{2}$. Through various business decisions which culminated in the cost of production reaching as little as USD 1.5 per barrel, Yukos was able to obtain capitalization at the level of USD 21 billion by 2003, becoming the first Russian company to be ranked among the top ten largest oil and gas companies worldwide.

There are two overriding aspects of Yukos and M. Khodorkovsky's dispute with Russia, i.e., political and business. M. Khodorkovsky was one of the Russian oligarchs who benefited immensely from the privatization of the Russian economy, in particular of its oil and gas sector. Whilst many appraised Russia and both President Yeltsin and Putin for the pro-market reforms, it was also indicated that: "the basic reforms and privatization of the 1990s were so flawed and unfair that they created an unstable business

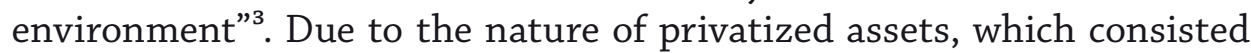
mainly of raw materials formerly belonging to the State, the well-being of oligarchs such as M. Khodorkovsky depended mostly on their relations with the Government. Those relations changed significantly once President Yeltsin was replaced by President Putin.

2 www.khodorkovsky.com; see also Veteran Petroleum v. Russia, at para. 71.

3 M. Goldman, Putin and the Oligarchs, 'Foreign Affairs' 2004, vol. 83, no. 6, p. 33, at p. 34 . 
The facts connected with the operations of Yukos before 2003 were not reviewed in-depth by the Tribunal. However, the context of the dispute requires a short description of Yukos' tax optimization scheme. The scheme was based on establishing trading companies in low-tax regions, which, as described in the Award: "were allowed to exempt taxpayers from federal corporate profit tax for the purpose of encouraging taxpayers' investments in their regions, provided the taxpayers complied with certain requirements"4. Yukos benefitted from this scheme, as did other Russian companies managed by oligarchs.

In 2003, for the reasons described below, Yukos was targeted by tax and criminal authorities with charges of tax evasion and fraud. The Russian tax authorities found that transactions with the use of companies in low-tax regions of Russia were a sham and abused tax law, and their practices were in violation of the "good faith" doctrine applied by both tax officers and courts in proceedings concerning Yukos. These findings led tax authorities to reassess Yukos' obligations and to impose multi-billion arrears. As a consequence, Yukos suffered a number of further hits, such as "repeated offender" fines, VAT arrears (due to an alleged failure by Yukos to file proper VAT documentation in lieu of the trading companies) and, most importantly, serious enforcement measures which ultimately led to the appropriation of Yukos' assets by other Russian companies, such as state-owned Rosneft.

As mentioned above, these measures have been put in the context of political and economic aspects of the dispute between Yukos and M. Khodorkovsky on the one hand, and Russia on the other.

The political perspective concerns $\mathrm{M}$. Khodorkovsky's involvement in a political campaign by supporting various political forces which were in opposition to President Putin. Primarily, as stated by the Russian former prime minister, M. Kasyanov, the main reason for the abovementioned measures, was the support given by M. Khodorkovsky and Yukos to the Communist Party ${ }^{5}$. Whilst supporting the opposition, M. Khodorkovsky also attacked President Putin accusing him and the whole administration of corruption. According to witnesses who testified during the arbitration proceedings, those accusations resulted in President Putin removing protection and support previously granted to Yukos and M. Khodorkovsky.

4 Veteran Petroleum v. Russia, at para. 280.

5 Kasyanov reveals Putin's pursuit of tycoon, 'Financial Times' 20.7.2009. 
The economic perspective concerns Russia's attempts to take over Yukos' valuable assets, in particular the oil production company Yuganskneftegaz ("YNG"). YNG was appropriated through an auction involving a "previously unknown entity called Baikal Finance Group" which was a "dummy that was used to mask the Russian State's interest and involvement in the process" ${ }^{\text {. }}$. YNG was sold during a short auction and later appropriated by the state-owned company Rosneft which subsequently became the leader of the Russian oil and gas company market. The manner of conducting the auction led the tribunal to conclude that:

[t]his episode provides yet more compelling evidence that the Russian Federation was not engaged in a true, good faith tax collection exercise but rather was intent on confiscating the most valuable asset of Yukos and effectively transferring it to the Russian State?

A review of the facts of the case may give rise to the conclusion that the will to take over Yukos' assets was at least as strong an incentive behind Russia's actions as was President's Putin attempts to eliminate M. Khodorkovsky as a potential political opponent.

Ultimately, Yukos was declared bankrupt on 4.8.2006 by the Moscow Arbitrazh Court. Its remaining assets were taken over primarily by Rosneft. As noted by the Tribunal, Russia held over 97 percent of all claims against Yukos and received, directly or through Rosneft, as much as 99.71 percent of the bankruptcy proceeds ${ }^{8}$. Yukos was struck off the register of companies and its shares were legally extinguished on 21.11.2007.

\section{The host State's regulatory and enforcement powers with respect to taxation}

One of the key questions raised in the Yukos cases concerned the scope of the host State's legitimate powers to regulate its tax system and proceedings. As stated by J. Crawford: "even in laissez-faire economies, the taking of private property for certain public purposes and the establishment

6 Veteran Petroleum v. Russia, at para. 982.

7 Ibidem, at para. 985.

8 Ibidem, at para. 1096. 
of state monopolies have long been familiar". Thus: "foreign assets and their use may be subjected to taxation, trade restrictions such as quotas, revocation of licences for breach of regulations, or measures of devaluation" ${ }^{10}$. It is a common understanding that measures which result from government activities which are deemed normal or typical, need not be treated as expropriation even if their effect is tantamount to taking ${ }^{11}$. This in particular applies to taxation. As stated by A.R. Albrecht: "It is generally accepted principle of international law that the right to tax, which is an aspect of sovereignty, extends to aliens"12.

As stated in the recent UNCTAD study on expropriation there is no universally accepted definition of the regulatory powers of a host State whose exercise may result in a non-compensatory taking ${ }^{13}$. Among different fields of such regulation, "seizure of property by way of taxation" is mentioned. Similarly, M. Sornarajah stated that: "It has always been recognized that ordinary measures of taxation or imposition of criminal penalties or export controls do not constitute taking that is compensable"14. Whilst the non-compensable nature of the ordinary State's tax measures is indeed widely recognized, it is much more disputable on what point the tax measure becomes a confiscatory taking that amounts to expropriation in violation of international investment law.

9 J. Crawford, Brownlie's Principles of Public International Law, $8^{\text {th }}$ Edition, Oxford 2012, p. 621. Similar view was expressed by, among others, M. Sornarajah who stated that: "The modern state, despite its adherence to an open economy, contains a substantial amount of regulatory mechanisms which control the economy". See M. Sornarajah, The International Law of Foreign Investment, Third Edition, Cambridge University Press 2010, p. 77.

10 Ibidiem.

11 As stated by the tribunal in the Saluka v. Czech Republic case: "the principle that a State does not commit an expropriation and is thus not liable to pay compensation to a dispossessed alien investor when it adopts general regulations that are 'commonly accepted as within the police powers of States' forms part of customary international law today"; Saluka Investments BV v. the Czech Republic, Award of 17.3.2006, at para. 262, available at www.italaw.com.

12 A.R. Albrecht, The Taxation of Aliens under International Law, 'British Yearbook of International Law' 1952, vol. 29, at p. 145.

13 UNCTAD Series on Issues in International Investment Agreements II. Expropriation. A Sequel., New York Geneva 2012, p. 79.

14 M. Sornarajah, op. cit., p. 374. 
With respect to regulatory measures in general, the OECD evaluation paper clarifies the issue to some extent ${ }^{15}$. According to OECD the following criteria has to be evaluated in determining to what extent a measure reaches the level of expropriation. Firstly, one has to evaluate the degree of interference of the measure with the property rights of an investor. Secondly, the character and purpose as well as the context of the measure must be taken into consideration. Finally, an arbitration panel resolving such dispute should confront the measure with reasonable investment-backed expectations of the investor. Bearing in mind the case law on taxation measures to date, the criteria to establish expropriation through taxation, should be even more stringent, as such measures need not qualify as expropriation even if their effect is expropriatory, i.e., even if they lead to a substantial deprivation of the investment's value. In general, this seems reasonable given all taxation measures have some confiscatory element in their nature. Thus, potentially, there are two elements in which the protection under IIAs may come into the picture. Firstly, international investment law seems to prohibit so-called confiscatory taxation. Secondly, international investment law pays attention to the way in which such taxes are imposed and tax law is applied. As stated in the Burlington v. Ecuador case: "Customary international law imposes two limitations on the power to tax. Taxes may not be discriminatory and they may not be confiscatory" ${ }^{16}$.

Confiscatory taxation may comprise a radical increase in taxes to unreasonable amounts or the introduction of a completely new tax. In both instances, if as a result of taxation, the foreign investor is effectively deprived of the investment, the question as to the compensation for such taxation measure arises. However, a few issues need to be considered. In particular, it is doubtful that a mere increase of the level of taxation, if not discriminatory, may be qualified as expropriation given it is a normal policy issue to increase or lower taxes depending on the state of the economy. Furthermore, if an increase affects the whole host State's economy, the foreign investor need not be in a worse position than local entrepreneurs and thus, his position may not necessarily weaken. On the other hand, taxation may be treated as a means to nationalize the whole economy and this would create a compensable nationalization in accordance

$15 \mathrm{OECD}$, 'Indirect Expropriation' and the 'Right to Regulate' in International Investment Law, OECD Working Papers on International Investment 2004/04.

${ }_{16}$ Burlington Resources Inc. v. Republic of Ecuador, Decision on Liability of 14.12.2012, ICSID Case No. ARB/08/5, at para. 393. 
with international law ${ }^{17}$. Consequently, it is extremely difficult to strictly delimit the boundary between what is burdensome and yet allowed, and what is confiscatory or expropriatory. As suggested in Article VIII of the Multilateral Agreement on Investment prepared by the OECD in $1998^{18}$, to decide if a particular tax measure constitutes taxation it is necessary to look at whether that measure is within "the bounds of internationally recognized tax policies and practices" ${ }^{19}$. Vitally, from the perspective of the Yukos Awards, the MAI also suggested that "taxation measures aimed at preventing the avoidance or evasion of taxes should not generally be considered to be expropriatory" ${ }^{20}$. Hence, the purpose of the taxation measure seems to be determinative. If the measure is adopted to deprive the investor of his property, it may constitute an expropriation in breach of the international obligation of a host State ${ }^{21}$.

As mentioned, the taxation measures are expropriatory if applied in a manner which deprives the foreign investor of his investment. Thus what counts is the way in which the measures are introduced and applied by tax authorities of a host State rather than the mere fact that taxes are burdensome ${ }^{22}$. To set an example, in the RosInvest $v$. Russia case, which is yet another case concerning Russia's expropriation of Yukos, the tribunal found that:

[t]he Russian tax authorities may change their positions regarding interpretation and application of the tax law and that they have a certain discretion in this respect. However, if such changes and the use of discretion occur in so many respects and regarding a particular tax payer as compared with the treatment accorded to comparable other

17 See, for instance, Resolution of the UN General Assembly No. 1803(XVII), adopted on 14.12.1962.

18 Whilst the text of MAI was discussed heavily between 1995 and 1998, in December 1998 the OECD Member States decided to cease works on the agreement. For the story of negotiations over MAI see: www.oecd.org/daf/mai/intro.htm .

19 Consolidated text of MAI, adopted by the Negotiating Group on Multilateral Agreement on Investment on 22.4.1998; OECD Doc. No. DAFFE/MAI(98)7/REV1, at p. 86.

20 Ibidem.

21 Burlington v. Ecuador, supra note 13, at para. 394. See also Restatement (Third) of the Law of Foreign Relations, published by the American Law Institute in 1965, at p. 200.

22 A.R. Albrecht, op. cit., at p. 173. 
tax payers, doubts remain regarding the objectivity and fairness of the process ${ }^{23}$.

In other words, international law imposes certain limitations on the host State's discretion as to the imposition and enforcement of taxes.

The host State violates its obligations under IIAs when a taxation measure is imposed in a discriminatory and arbitrary manner. The most striking example of such discriminatory and arbitrary manner would be to violate the basic principles of due process of law during tax proceedings either before tax authorities or before a court. These principles induced the Tribunal in the Yukos case to decide on Russia's responsibility under the Energy Charter Treaty.

In the Yukos Case, the taxation measures comprised of various arrears imposed on Yukos due to the optimization scheme adopted by Yukos with the use of trading companies established in low-tax regions. Yukos' optimization scheme used the legislation in place in Russia at those times. However, Russia claimed that the scheme was a pure sham. Whilst it was in agreement with the formal requirements of Russian law, the scheme violated a "substance over form" doctrine apparently well established in Russia. The doctrine comprised of a typical general clause preventing abuse of law by merely respecting its words. This led the Tribunal to state that:

[i]t was open to the Russian authorities and the courts to rely on the 'bad faith taxpayer' doctrine to challenge a tax evasion scheme at the time of the Yukos tax assessments, whether based on 'substance over form' or 'business purpose'. Although this was an area of the law that was evolving at the time, this alone cannot be determinative. Indeed, the anti-abuse doctrine was a judicial doctrine, and the Tribunal does not consider it appropriate to criticize the Russian Federation only because such a doctrine had not yet fully crystalized ${ }^{24}$.

Whilst it is agreeable that States have a wide margin of discretion with respect to their taxation policy ${ }^{25}$, it may be troubling when that wide margin is applied so broadly as in the instance of the "substance over form" doctrine. What was lacking in the Yukos Case was an elaboration by the Tribunal of the relationship between that doctrine, which admittedly was

23 RosInvest UK Ltd. V. The Russian Federation, Award of 12.9.2010, at para. 496; available at www.italaw.com.

24 Veteran Petroleum v. Russia, at para. 614.

25 See also G. Van Harten, Sovereign Choices and Sovereign Constraints, Oxford University Press 2013, at pp. 110-111. 
not yet developed during Yukos' tax proceedings and the obligation to keep a stable and predictable legal framework for an investment ${ }^{26}$. On the one hand, one cannot question the right of a host State to fight tax evasion. On the other hand, limiting instances of the State's liability for taxation measures only to instances of bad faith taxation, as was the case with respect to Yukos, is certainly at odds with the common understanding of indirect or creeping expropriation. In other words, when the State applies its tax law to fight tax evasion in breach of its obligation to secure a stable and predictable legal framework, it should bear responsibility under IIA irrespective of whether it acted in good or bad faith. This issue is discussed more comprehensively in the next section. However, it is important to underline the necessity to look at taxation measures based on such concepts as "substance over form" more carefully, so to ensure that they are not misused by host States, even where this does not involve bad faith - which would be difficult to establish.

\section{Does expropriation through taxation measures require the host State's bad faith?}

In international investment law, the notion of expropriation is based first and foremost on the sole-effect doctrine. As stated in the famous passage of the Metalclad v. Mexico case:

expropriation under NAFTA includes not only open, deliberate and acknowledged takings of property, such as outright seizure or formal

26 It is worth mentioning how other arbitration tribunals or international courts approached the Russia's policy against allegations of tax evasion by Yukos. The tribunal in the Quasar de Valores v. Russia case found that: "To characterise behaviour as violating a broad concept of "good faith" when a taxpayer adopts behaviour precisely to take advantage of tax benefits created with the intention of inducing the corresponding conduct seems quite extraordinary". See Quasar de Valores SICAV SA, Orgor de Valores SICAV SA, GBI 9000 SICAV SA, ALOS 34 SL v. The Russian Federation, Award of 20.7.2012, at para. 65. Available at www.italaw.com. On the other hand, the European Court of Human Rights faced with the complaint by Yukos of violation, in the course of tax proceedings against Yukos, of Article 6 of the European Convention on Human Rights and Fundamental Freedoms (right to fair trial) and Article 1 of Protocol 1 (Protection of property) rejected the complaint except complaint concerning tax proceedings for the tax year 2000; See OAO Neftyanaya KompaniyaYukos v. Russia, Application No. 14902/04, Judgment of 8.3.2012. 
or obligatory transfer of title in favour of the host State, but also covert or incidental interference with the use of property which has the effect of depriving the owner, in whole or in significant part, of the use or reasonably-to-be-expected economic benefit of property even if not necessarily to the obvious benefit of the host State ${ }^{27}$.

In other words, before turning to the issue of legality of the measure, it is necessary to find whether that measure interfered in an investor's property to an extent sufficient to state that he was deprived of the use or economic benefit of the investment.

On the contrary, with respect to measures which are usually treated as normal exercise of sovereign powers, the intent may enhance determination of the legality or illegality of the measure tantamount to expropriation. As stated in the interpretation notes of the OECD Draft Convention on Foreign Property, adopted in 1967:

By using the phrase 'to deprive...directly or indirectly...' in the text of the Article it is, however, intended to bring within its compass any measures taken with the intent of wrongfully depriving the national concerned of the substance of his rights and resulting in such loss (emphasis in original) ${ }^{28}$.

The note continues to state that:

Article 3 is meant to cover 'creeping nationalisation', recently practiced by certain States. Under it, measures otherwise lawful are applied in such a way at to deprive ultimately the alien of the enjoyment or value of his property, without any specific act being identifiable as outright deprivation"29.

This statement seems to suggest that two elements are needed to find an unlawful expropriation, i.e., both effect and intent. However, investment arbitration tribunal case-law demonstrates that: firstly, intent is hard to establish and, secondly, not needed if other requirements for expropriation are met, such as the lack of public purpose, discrimination or violation of due process.

The Yukos Awards contain extensive argumentation as to Russia's intent behind the expropriation of Yukos. The reasoning supplied by the

27 Metalclad Corporation v. United Mexican States, Award of 30.8.2000, ICSID Case No. ARB(AF)/97/1, at para. 103.

${ }^{28} 1967$ OECD Draft Convention on Foreign Property, available at www.oecd.org, at pp. 18-19.

${ }^{29}$ Ibidem, at p. 18. 
Tribunal seems to convey that if it was not for Russia's and V. Putin's intent to destroy Yukos and M. Khodorkovsky as a political opponent, no violation of ECT would have taken place. The main Yukos' argument, endorsed by the Tribunal, was that all actions and omissions of Russia taken together with respect to Yukos' tax proceedings reveal a pattern of intentional conduct which qualifies as creeping expropriation. Consequently, the Tribunal elaborated on the intent issue by stating that: "it would therefore be artificial to deal with the complexity of this case by deconstructing the various elements of the tax assessments without, in the end, taking the broader perspective that is required to properly appreciate each one of them" ${ }^{30}$. As requested by the Claimants, the Tribunal adopted the general approach by reviewing the whole structure of the tax dispute between Russia and Yukos rather than by looking at each instance of Russia's conduct separately. It is intriguing that the Tribunal did not refer to Article 15 of the International Law Commission's Articles on State Responsibility for Internationally Wrongful Acts ("ILC Articles") ${ }^{31}$ stipulating the rules of responsibility for composite acts. The ILC Articles clearly assert that a State is responsible for a series of actions or omissions which may be defined together as a wrongful act. Indeed, the concept of composite act could easily be applied to the Yukos Case to establish creeping expropriation without the need to determine Russia's intent behind that expropriation. However, it seems that the Tribunal treated the intent as a merging factor combining all the complained actions by Russian authorities against Yukos.

The Tribunal's reliance on intent also had another dimension. Evaluating the applicability of the so-called "taxation carve-out" provision embodied in Article 21(1) of the ECT ${ }^{32}$, the Tribunal found that:

[t]he carve-out of Article 21(1) can apply only to bona fide taxation actions, i.e., actions that are motivated by the purpose of raising general revenue for the State. By contrast, actions that are taken only under the guise of taxation, but in reality aim to achieve an entirely unrelated purpose (such as destruction of a company or the

30 Veteran Petroleum v. Russia, at para. 608.

31 ILC Articles on State Responsibility for Internationally Wrongful Acts of 2001, Yearbook of the International Law Commission 2001, vol. II (Part II).

32 Pursuant to Article 21(1) of the ECT: „Except as otherwise provided in this Article, nothing in this Treaty shall create rights or impose obligations with respect to Taxation Measures of the Contracting Parties. In the event of any inconsistency between this Article and any other provision of the Treaty, this Article shall prevail to the extent of the inconsistency". 
elimination of a political opponent) cannot qualify for exemption from the protection standards of the ECT under the taxation carveout in Article 21(1) ${ }^{33}$.

Seemingly, the Tribunal found that mala fide of Russia was so evident that there was no need to discuss the nature of taxation measures. In fact, the Tribunal based its determination of Russia's conduct as expropriatory on the fact that: "the primary objective of the Russian Federation was not to collect taxes but rather to bankrupt Yukos and appropriate its valuable assets". As stated above, these circumstances would have been more properly dealt with by the Tribunal through discussing the requirements of the legality of expropriation, whereas to establish if indirect, creeping expropriation took place, a review of the effect of the measures would have sufficed.

\section{Contributory Fault and its impact on Russia's responsibility}

The issue of relationship between Yukos' conduct and Russia's reaction to it has justifiably attracted a great deal of attention from international investment law scholars ${ }^{34}$. This is understandable given the consequences drawn by the Tribunal from the Claimants' conduct, i.e., a decrease in the amount of damages by 25 percent $^{35}$. At the same time, the manner in which the Tribunal applied the institution of contributory fault requires thorough review and comment. Whilst in principle the applicability of the institution to situations similar to the Yukos case could hardly be questioned, the Tribunal's application featured a number of errors which could have been easily avoided.

There are two possible levels on which the concept of contributory fault could have been reviewed. Firstly, the Tribunal should have reviewed the fault of the Claimants in its determination of the existence of a causal link between Russia's conduct capable of violating the ECT and the damage

33 Veteran Petroleum v. Russia, at para. 1407, emphasis added; See also at paras. 1430-1431.

${ }^{34}$ See, for instance W. Sadowski, Yukos and Contributory Fault, Transnational Dispute Management 2014, available provisionally at www.transnational-dispute-management. com.

35 From USD 66,7 billion to USD 50 billion. 
suffered by the Claimants. That review has two components. The first component consists in the need to find an answer as to whether the expropriatory effect would not have occurred had it not been for Yukos' conduct. The second component comprised an equally important question as to whether Yukos's conduct, in normal circumstances, would bring about the expropriatory effect irrespective of Russia' conduct. Secondly, one must review the impact of Yukos' conduct on the amount of injury suffered in the established circumstances of the case. Both abovementioned components emanate from the general theory of causation in $\mathrm{law}^{36}$ which, though not explicitly, is endorsed in international law. At the same time, the comment below on the application of the contributory fault concept in the Yukos Cases is based on the assumption that the facts which formed the basis for the Tribunal's determination are accepted as described in the awards.

\subsection{General theory of causation and international (investment) law}

There is no general theory of causation in international law. This is mostly due to the fact that the theory of responsibility in international law is based on general concepts which are tentatively codified in the ILC Articles. The ILC Articles is a non-binding instrument and its authority is based on how the rules of responsibility stipulated therein are applied by international courts and tribunals ${ }^{37}$. With respect to causation, the ILC Articles does not prescribe any detailed rules except vague statements in Article 31(1) that: "the responsible State is under an obligation to make full reparation for the injury caused by the internationally wrongful act" (emphasis added). This statement is qualified by Article 36(1) on compensation to the effect that: "the State responsible for an internationally wrongful act is under an obligation to compensate for the damage caused thereby, insofar as such damage is not made good by restitution" (emphasis added) ${ }^{38}$.

${ }^{36}$ For general theory of causation in the law see: H.L.A. Hart, T. Honoré, Causation in the Law, $2^{\text {nd }}$ edition, Clarendon Press 1985.

37 J. Crawford, S. Olleson, The Continuing Debate on a UN Convention on State Responsibility, 'International and Comparative Law Quarterly' 2005, vol. 54, no. 4, at p. 966.

38 The ILC Articles was critisized for that ommission in B. Stern, The Obligation to Make Reparation, [in:] J. Crawford, A. Pellet, S. Olleson (eds.), 'The Law of International 
From the perspective of causation the implications of those provisions are twofold. Firstly, it is clear that there must be a causal link between an action or omission by a State and the injury suffered. Secondly, that the State is responsible only for injury suffered as a result of the internationally wrongful act. At the same time, it should be noted that the injury as such is not mentioned as a prerequisite for State responsibility and, according to J. Crawford - the ILC's Special Rapporteur on State responsibility the responsibility in international law is an objective (or absolute) one ${ }^{39}$. Whilst it is hard to imagine an international investment dispute without an investor's claim for damages, the same rule applies in international investment law. Consequently, a host State may be responsible for violation of obligations under IIA irrespective of the harm suffered by an investor. Thus, no causal link need be established at this stage.

However, to establish both the form and scope of the host State's responsibility a causal link must be established (though without re-reviewing the issue of existence of an internationally wrongful act). As stated by J. Crawford: "the notion of sufficient causal link which is not too remote is embodied in the general requirements in Article 31 that the injury should be in consequence of the wrongful act, but without the addition of any particular qualifying phrase" ${ }^{\text {.0 }}$. The concept of causation stipulated in the ILC Articles was developed by J. Crawford in his more recent treatise on International Responsibility in which he stated that: "the allocation of injury to a wrongful act is in principle a legal process" ${ }^{41}$. This means that apart from the normal, factual review of the relationship between cause and effect (i.e., whether without the cause no injury was suffered), a review as to whether the injury is not too remote an effect of the internationally wrongful act is required. In fact, to establish a "sufficient causal link" a detailed review of the whole factual and legal picture is needed involving an evaluation of different alternative or simultaneous causes and occasionally even of complex chains of causation in which the injury is a final cause of different factors which depend on each other.

Responsibility', Oxford University Press 2010, at p. 570.

${ }^{39}$ J. Crawford, The ILC's Articles on State Responsibility: Introduction, Text and Commentaries, Cambridge University Press 2002, at p. 1.

40 Commentary to the ILC Articles on Responsibility of States for Internationally Wrongful Acts, 'ILC Yearbook' 2001, vol. II, at p. 93.

41 J. Crawford, State Responsibility. The General Part, Cambridge University Press 2013, at p. 492. 
In international investment law, the issue of causation requires a focused approach. As rightly pointed out by D. Shelton: "causation is a complex issue in every legal system, where the extent of liability for remote events and the consequences of intervening causes may vary considerably from one area of the law to another" ${ }^{\prime 2}$. The focused approach necessitates looking into the economic realities of a particular investment lost or harmed by a host State's conduct and also the business environment at the time of the investment and at the time of the alleged internationally wrongful act. In particular, an investment arbitration tribunal has to examine if the economic misfortune of the investor is not due to his own negligence or, from time to time, his unlawful conduct. Such a situation was also discussed by ILC with respect to general rules on responsibility and it expressed the principle in a more encompassing notion of "concurrent causes" ${ }^{43}$. This notion covers all factors that may have contributed to the injury of which the internationally wrongful act is just one. In such situation, both the ILC Articles and case-law agree that the obligation to repair an injury arises irrespective of the causal link between those other causes and the injury ${ }^{44}$. It is a logical consequence of the abovementioned rule which does not require an injury for establishing the internationally wrongful act. Thus, if there is an internationally wrongful act which, among other factors, caused injury to another entity, then the obligation to repair harm arises.

Another rule refers to the contribution by an injured entity to the harm suffered. Such situation found its expression in the ILC Articles themselves. According to Article 39: "in the determination of reparation, account shall be taken of the contribution to the injury by willful or negligent action or omission of the injured State or any person or entity in relation to whom reparation is sought". Therefore, it is clear that an evaluation of the injured State's conduct and its impact on the injury is only assessed at the time of calculating damages and is of no relevance to establishing if an internationally wrongful act occurred unless it is part of the primary rule ${ }^{45}$.

42 D. Shelton, Righting Wrongs: Reparations in the Articles on State Responsibility, 'American Journal of International Law' 2002, vol. 96, no. 4, at p. 846.

43 See supra note 40, at p. 93.

44 See, for instance, Ethiopia's Damages Claims (The Federal Democratic Republic of Ethiopia v. The State of Eritrea), Final Award of 17.8.2009, at para. 330, available at www.pca-cpa.org.

${ }_{45}$ The notion of primary rule refers to H.LA. Hart's "Concept of Law" whereby a primary rule determines the conduct of persons whereas secondary rule determines 
In the international investment law régime the aspect of difference between primary and secondary norms is not easily established. On the one hand, it is clear in a situation when an investment is made contrary to municipal law. Most IIAs do not grant protection to such investments and international investment tribunals reject jurisdiction over claims referring to such investments ${ }^{46}$. Thus, in such situations no internationally wrongful act occurs as the violation of the host State's law is evaluated at the level of primary rules. On the other hand, recent case-law, including the commented case, evaluate the investor's misconduct only at the stage of calculating damages under the guise of "contributory fault" 4 . Whilst those tribunals review the investor's misconduct during a review of the internationally wrongful act element, the review shall also have an impact on the amount of damages awarded.

\subsection{Contributory fault and the Yukos Awards}

In the Yukos Awards, Russia used the following argument: no matter what measures were undertaken by the Russian tax authorities or courts, these measures constituted a legitimate response to the tax evasion scheme adopted by Yukos in contravention to Russian municipal law. The Tribunal's response to that defense must have been based on the assumption, discussed in point (3) above, that States can react to violations of their tax legislation using mechanisms available under their laws. Consequently, the Tribunal stated that: "the expectations of Claimants may have been, and

how primary rules are to be stipulated, interpreted and applied. See H.L.A. Hart, The Concept of Law, Clarendon Press 1961, at p. 77 et seq.

46 See, for example: Inceysa Vallisoletana, S.L. v. The Republic of Salvador, Award of 2.8.2006, ICSID Case No. ARB/03/26, at para. 257. In the MTD v. Chile case the tribunal went even further asserting that even in case of investor's negligence he should be blamed for that and, accordingly, such negligence should have impact on the scope of a host State's responsibility by decreasing the amount of damages by 50 percent. See MTD Equity Sdn. Bhd. and MTD Chile S.A. v. Republic of Chile, Award of 25.5.2004, ICSID Case No. ARB/01/7, at para. 243.

47 In the Occidental v. Ecuador case, the tribunal found that claimant breached the contract but the reaction of Ecuador was not proportional. Consequently, the tribunal decreased the amount of damages by 25 percent. See Occidental Petroleum Corporation, Occidental Exploration and Petroleum Company v. The Republic of Ecuador, Award of 5.10.2012, ICSID Case No. ARB/06/11, at para. 687. 
certainly should have been, that Yukos' tax avoidance operations risked adverse reaction from Russian authorities" ${ }^{48}$. The Tribunal did not refrain from calling the tax avoidance scheme adopted by Yukos as a sham ${ }^{49}$. This had to be confronted with Russia's contention that: "Claimants may not recover from the Russian Federation the fruits of their own wrongdoing" Consequently, the tribunal concluded that: “it cannot ignore that Yukos' tax avoidance arrangements in some of the low-tax regions made it possible for Respondent to invoke and rely on that conduct as justification of its actions against Mr. Khodorkovsky and Yukos"51. Finally, referring to the causation theory, the Tribunal established: "that there is a sufficient causal link between Yukos' abuse of the system in some of the low-tax regions and its demise which triggers a finding of contributory fault on the part of Yukos" ${ }^{52}$. The Tribunal's review of Yukos' contributory fault led to a 25 percent reduction of damages awarded, to approximately Euro 50 billion.

For the purpose of the present paper it is assumed that the Tribunal's evaluation of Yukos' tax optimization scheme as a sham was correct, despite an apparent lack of precise legal grounds under Russian law to reject using trade entities established in low-tax regions of Russia as a typical (and not an explicitly prohibited) mechanism to benefit from differences in taxation. Such mechanisms are commonly and legitimately used by companies all over the world. However, the Tribunal is given credit for its admittedly comprehensive assessment of the factual record of the case in the context of Russian law. Therefore, the question arises as to whether "fault" attributed to Yukos contributed to the injury in such a way which could have justified a 25 percent reduction in the amount of damages. Answering that question requires a practical application of Article 39 of the ILC Articles.

As already discussed, at this time, it is important to distinguish the issue as to whether Yukos' conduct ${ }^{53}$ justified a reaction from Russia and whether such reaction was proportionate, from the issue as to whether Yukos' conduct was irrelevant as it merely constituted a pretext for Russian authorities to take over its assets and to punish its officials for their political

48 Veteran Petroleum v. Russia, at para. 1578.

49 Ibidem, at para. 515.

50 Ibidem, quoting Respondent's Opening Statement, at para. 1594 (footnote omitted).

51 Ibidem, at para. 1614.

52 Ibidem, at para. 1615.

53 On other contributory factors. See W. Sadowski, op. cit., at p. 20 et seq. 
engagement. As stated by H.L.A. Hart and T. Honoré: “Plaintiff's negligence is of legal significance only if causally connected with the harm" ${ }^{54}$. In turn, the key question is whether had it not been for Yukos' conduct, would the harm have been the same as in reality? The answer is straightforward. The Tribunal established, as a matter of factual record, that the alleged tax irregularities were merely a pretext for taking over Yukos' shares, and that there was no need to inquire into alternative scenarios of other possible pretexts which could have led to the same result. Whilst intent was not required to establish Russia's responsibility for the unlawful expropriation of Yukos, intent predetermines Russia's responsibility for all harm incurred by the Claimants no matter what pretext they may have given ${ }^{55}$. However, the (allegedly) unlawful conduct of Yukos could not have been disregarded by the Tribunal. It was noted by the Tribunal that Yukos was aware that by adopting the tax optimization scheme it exposed itself to a negative reaction from Russia. From a causation theory perspective, since Yukos voluntarily exposed itself to the tax responsibility, it should be treated as partially responsible for its own fate. Thus, the Tribunal was entitled to reduce the award in proportion to Yukos' contribution to the injury ${ }^{56}$.

Notwithstanding the theoretical determination of the impact of Yukos' own misconduct on the injury, the practical approach requires a constructive review of the ultimate result, i.e., a reduction of 25 percent in the awarded damages. At no point has the Tribunal explained how or why Yukos' contribution was calculated at that particular level. In the words of the Tribunal: "as a result of the material and significant mis-conduct by Claimants and by Yukos (which they controlled), Claimants have contributed to the extent of 25 percent to the prejudice which they suffered as a result of Respondent's destruction of Yukos"57. Seemingly, the Tribunal went beyond a mere calculation of Yukos' potential tax liabilities in a nobreach scenario and used its discretion to not assess the impact of Yukos' conduct on the injury suffered but to establish to what extent Yukos should be blamed for the internationally wrongful act that occurred. This could have been a factor taken into consideration in the review of the existence

54 H.L.A. Hart, T. Honoré, op. cit., at p. 208; This was discussed by the tribunal in the MTD v. Chile case in which the arbitrators decided to decreased the amount of damages by 50 percent noting the negligent business conduct of the claimant. See supra note 46 , at paras 242-246.

55 Veteran Petroleum v. Russia, at para. 516.

56 See, W. Sadowski, op. cit., at p. 26 et seq.

57 Veteran Petroleum v. Russia, at para. 1637. 
of a causal link between the internationally wrongful act and the injury suffered under Article 31 of the ILC Articles but is of no relevance for the purpose of the application of Article 39. Instead, the Tribunal should have reduced the amount of damages by the amount of Yukos' legitimate tax liabilities, i.e., by approximately Euro 10.6 billion increased by any other legitimate consequences of the (allegedly) illegal tax avoidance scheme.

\section{The calculation of damages}

The commonly applied standard for reparations was stipulated by the Permanent Court of International Justice ("PCIJ") in the Chorzów Factory case $^{58}$. According to the PCIJ:

the essential principle contained in the actual notion of an illegal act a principle which seems to be established by international practice in particular by the decisions of arbitral tribunals - is that reparation must, as far as possible, wipe out all the consequences of the illegal act and reestablish the situation which would, in all probability, have existed if that act had not been committed.

This standard has also been reflected in the ILC Articles. As stated above, the relevant standard is that of full reparation for the injury inflicted ${ }^{59}$. Whilst general international law attaches primacy to restitution-in-kind, pecuniary compensation is due whenever restitution-in-kind is not practicable ${ }^{60}$. At the same time, according to Article 36(2) of the ILC Articles: "The compensation shall cover any financially assessable damage including loss of profits insofar as it is established" (emphasis added). The standard set by the Chorzów Factory judgment and by the ILC Articles was also confirmed and applied by investment arbitration tribunals ${ }^{61}$. As such, there can be no doubt that the standard reflects customary international law and in so doing is accepted in international investment law.

58 Case concerning the Factory at Chorzów (Claim for Indemnity), PCIJ Judgment of 13.9.1928, 'Publications of the Permanent Court of International Justice', Series A, No. 13 , at p. 47.

59 Commentary to the ILC Articles, supra note 40, at pp. 98-99.

60 See Article 36(1) of the ILC Articles.

61 See, for instance, Mr. Franck Charles Arif v. Republic of Moldova, Award of April 8, 2013, ICSID Case No. ARB/11/23, at para. 559. 
The broadly formulated obligation to "wipe out" all the consequences of the internationally wrongful act does not imply any particular method of calculating damages inflicted upon an injured investor ${ }^{62}$. However, any evaluation of tribunals' calculations should be made through the lenses of the obligation to bring about a situation which would have existed should the responsible State had not committed an internationally wrongful act. From the perspective of the present case comment, the key problem concerns a calculation of the value of damages after the harm was already suffered which covers the benefits reasonably to be expected by the investor. The difficulty connected with calculating the loss of profit for the purpose of awarding damages is connected with the requirement set by Article 36(2) of the ILC Articles, that to establish what would be the status quo ante of the investment lost, the lost profits should be at least probable ${ }^{63}$. In situations such as the one discussed in the present case, such calculation could be made on the basis of the discounted cash flow method ("DCF") which allows calculating the value of a company at any given point of time with knowledge of data regarding its past cash flow. This would allow for determination of the value of a company whilst it was a going concern and, consequently, disregard the unnatural factor of internationally wrongful $\mathrm{act}^{64}$.

In the Yukos case, the factual record apparently shows that whilst Yukos was taken over by the State, its assets continued to produce profit and in that sense the companies may partially be treated as an ongoing concern. Despite this, the Claimants proposed a number of valuation methods, including the DCF and comparable companies methods, with values ranging from app. Euro 75 billion to app. Euro 125 billion. The Tribunal, without elaborating too much on this, decided to use the comparable companies

62 S. Ripinsky, K. Williams, Damages in International Law, BIICL 2008, at pp. 243246; I. Marboe, Calculation of Compensation and Damages in International Investment Law, Oxford University Press 2009, at p. 2.

63 Asian Agricultural Products Ltd. v. Republic of Sri Lanka, Award of 27.6.1990, ICSID Case No. ARB/87/3, at para. 104.

64 In the Simens v. Argentina case the tribunal convincingly stated that: „usually, the book value method applied to a recent investment is considered an appropriate method of calculating its fair market value when there is no market for the assets expropriated. On the other hand, the DCF method is applied to ongoing concerns based on the historical data of their revenues and profits; otherwise, it is considered that the data is too speculative to calculate future profits". See Siemens A.G. v. The Argentine Republic, Award of 6.2.2007, ICSID Case No. ARB/02/8, at para. 355. 
method and reject DCF claiming that the Claimants' expert had erred. However, the Tribunal did not provide with the independent evaluation of the utility of that method. In general, the Tribunal's calculation of damages should be criticized for a lack of comprehensive explanation as to how the result achieved refers to the international law compensation standard.

The Tribunal's key contention with respect to the methodology of calculating damages was that:

[i]nvestors must enjoy the benefits of anticipated events that increase the value of an expropriated asset up to the date of the decision, because they have a right to compensation in lieu of their right to restitution of expropriated asset as of that date ${ }^{65}$.

The Arbitrators seem to suggest that the restitution in kind would result in returning the taken-over assets of Yukos in the current state without any need to calculate, among others, the costs that Yukos would have incurred to obtain the same status in a no-breach scenario. The Tribunal's statement is at odds with the Chorzów Factory standard which does not require an examination of the current state of the property taken by the State but an examination of a hypothetical scenario, based on a number of factors (such as previous cash flows or sufficiently proved prospects), demonstrating the situation had it not been for a violation of the international obligation. Significantly, the Tribunal mistakenly evaluated the practicability of the restitution in kind in the context of the case, as this was precisely because any restitution would not bring about a status quo ante (as it would require giving back assets which are now operating under completely different circumstances) that makes such restitution impracticable. Otherwise, the Tribunal would be fully entitled to order such restitution as a first step of reparation of the damage incurred by Yukos. Instead, the Tribunal should have evaluated the hypothetical scenarios based on a DCF calculation (corrected, if necessary, by the Tribunal's appointed expert) and on reviewing the probability of different scenarios presented by the Claimants during proceedings. This would have allowed for Yukos' value to have been calculated for any date and bring about the situation which, in all probability, would have existed had it not been for the internationally wrongful act of Russia.

Veteran Petroleum v. Russia, at para. 1767. 


\section{Conclusion}

The landmark nature of the Yukos Awards is obvious to all lawyers, even those practicing outside the international investment law community. The political nature of the dispute as well as the circumstances in which the Awards were rendered make them particularly interesting and, in consequence, prone to criticism. And yet, the Arbitrators were faced with complicated legal issues and their evaluation of those issues will certainly have an impact on other cases. The Author believes that the issues commented in the present case-comment required a review. The Arbitrators, who comprehensively reviewed the factual record of the case, at some point decided to not undertake a more subtle and precise legal analysis. This was particularly so in those instances where the Tribunal used its discretion, such as in its assessment of the value of contributory fault of Yukos and in choosing the method for the calculation of damages. Consequently, the Awards will also inspire broad discussion with respect to challenges in the international investment arbitration arena. 